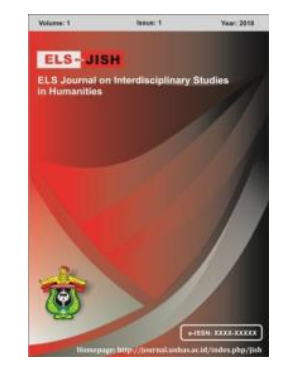

ELS-JISH

ELS Journal on Interdisciplinary Studies on Humanities

Volume 3 Issue 1, 2020

ISSN (print) : 2621-0843

ISSN (online) : 2621-0835

Homepage : http://journal.unhas.ac.id/index.php/jish

\title{
Translation Technique of English to Indonesian Subtitle in "Crazy Rich Asian" Movie
}

\author{
Tira Nur Fitria ${ }^{1}$ \\ ${ }^{1}$ tiranurfitria@gmail.com
}

\begin{abstract}
This objective of the research is to classify the types of translation technique from English to Indonesian subtitle, to determine the most dominant type of translation technique of English to Indonesian subtitle of "Crazy Rich Asian" movie. This research is descriptive qualitative research. It presents the problem clearly based on the most accurate data, explaining and describing the topic of a problem based on the theory used. The technique of collecting data used is documentation. There are 8 types of translation techniques found in the subtitle Crazy Rich Asian movie. The type of translation techniques used are Shift/Transposition as 72 data or $19.46 \%$, Literal as 70 data or $18.92 \%$, Established Equivalence as 62 data or $16.76 \%$, Reduction/Omission as 53 data or $14.32 \%$, Borrowing as 52 data or $14.05 \%$, Addition/Amplification as 30 data or $8.11 \%$, Modulation as 26 data or $7.03 \%$ and Adaptation as 5 data or $1.35 \%$. While the most dominant type of translation technique of English to Indonesian subtitle of "Crazy Rich Asian" movie is shift/transposition.
\end{abstract}

Keywords: Translation Technique, Subtitle, Movie.

How to cite: Fitria, T. N. (2019). Translation Technique of English to Indonesian Subtitle in "Crazy Rich Asian" Movie. ELS Journal on Interdisciplinary Studies in Humanities, 3(1), 51-65. DOI: http://dx.doi.org/10.34050/els-jish.v3i1.8415

\section{Introduction}

Translation is a mental activity in which the meaning of given linguistic discourse is rendered from one language to another (Osman, 2017). It is the act of transferring the linguistic entities from one language into their equivalents in another language. Translation is the communication of meaning from one language (the source) to another language (the target). Translation refers to written information, whereas interpretation refers to the spoken information. The purpose of translation is to convey the original tone and intent of a message, taking into account cultural and regional differences between the source and target languages. Translation has been used by humans for centuries, beginning after the appearance of written literature. Two languages are involved those are Indonesian as a source language (SL) and English as the target language (TL). Torres (2003: 57) states that the reasons for using these two languages are that English is one of the top 10 languages used worldwide, and

1,2,3 STIE AAS Surakarta, Indonesia. 
the Indonesian language is the national language of where this research conducted.

Translators have a lot of different things to consider before diving into translating a text (Rowan, 2014). The discrepancies in grammar and vocabulary between their different languages make it difficult to literally translate every text into word for word. In order to account for this, translators are able to use a wide variety of translation techniques in order to translate any given text accurately.

Hopwood (2016) state that a translator considers many elements before the actual translation is done. There could be discrepancies in vocabulary and grammar in both languages that means the literal translation is not possible. That is why these translation techniques are used to come up with an accurate translation.

Translation technique is defined as the realization of the translation process such as method and strategy of translation. According to Molina \& Albir (2002: 508), it refers to translation product and works for the micro unit of the text. However, the translation technique constantly misunderstood with the term of a method and strategy, translation due to the confusion between the translation process and translation product. Furthermore, Molina states that over-lapping terms make it difficult to be understood as well.

According to Molina and Albir (2002: 510-511), there are 18 kinds of translation techniques, namely: 1) Adaptation, 2) Amplification, 3) Borrowing, 4) Calque, 5) Compensation, 6) Description, 7) Discursive Creation, 8) Established Equivalence, 9) Generalization, 10) Linguistic Amplification, 11) Linguistic Compression, 12) Literal Translation, 13) Modulation, 14) Particularization, 15) Reduction, 16) Substitution 17) Transposition, and 18) Variation.

Subtitling or subtitle is one of a major part in a film or movie. Subtitling means that written captions in another language are shown at the bottom of the film, which must be synchronized with the film's dialogue for each scene (Racoma, 2015). Almost the movie which released in Indonesia contains the subtitle, both English and Indonesia. As there are many kinds of the movie in the world with the different language, the translator can choose a movie which is interesting for them. Almost the movie which released in Indonesia contains the subtitle, both English and Indonesia (Fitria, 2019). One of them is "Crazy Rich Asian" movie which released in recent times.

"Crazy Rich Asian" is an American romantic comedy-drama film directed by Jon M. Chu, from a screenplay by Peter Chiarelli and Adele Lim. It is based on the 2013 novel of the same name by Kevin Kwan. The film stars Constance Wu, Henry Golding, Gemma Chan, Nico Santos, Lisa Lu, Awkwafina, Ken Jeong, and Michelle Yeoh. It follows a Chinese American professor who travels to meet her boyfriend's family and is surprised to discover they are among the richest in Singapore. The film was announced in August 2013 after the rights to the book were purchased. Much of the cast signed on in the spring of 2017, and filming took place from April to June of that year in parts of Malaysia and Singapore. The popular Kevin Kwan book series Crazy Rich Asians showcase the fictional life and times of Asia's super wealthy (Seah, 2018). Crazy Rich Asians dominated the box office last summer and became the most successful 
romantic comedy in a decade. To date, the film has grossed more than $\$ 238$ million worldwide, NBD (Truong, 2019).

In this research, the writer focuses on the subtitle translation of the movie. This objective of the research is to classify the types of translation technique from English to Indonesian subtitle, to determine the most dominant type of translation technique of English to Indonesian subtitle of "Crazy Rich Asian" movie.

This research is related to the previous study, which is written by Fitria (2019) entitled Translation Technique of English into Indonesian Subtitle in "Bhaijan Bajrangi" Movie. This objective of the research is to classify the types of translation technique from English to Indonesian subtitle, to determine the most dominant type of translation technique of English to Indonesian subtitle of "Bhaijan Bajrangi" movie. This research is related to the previous research above. The similarity is about the topic, the theory of translation technique, and the kind of the data. The topic is related to the subtitle movie, and also its translation both English and Indonesian. The similarity between this research and the previous research is a type of translation technique which is proposed by Molina \& Albir. But there are many differences, for example, in the aim of the study about 1) data source and 2) the amount of the data, and 3) the results of data in this research.

\section{Method}

\subsection{Research Design}

The research design is a systematic attempt to do something which is used by the researcher to collect the data of his/her research (Arikunto, 2002: 9). This research is descriptive qualitative research since it described the translation procedures used by students. The type of data in this study is qualitative data. Qualitative data are usually in the form of words rather than a number.

According to Gay and Airasian (2000), descriptive qualitative research involves collecting data in order to answer concerns the current status of the object of the study and the research question. Descriptive research tries to present the problem clearly based on the most accurate data, explaining and describing the topic of a problem based on the theory used. Qualitative methods involve the collection and analysis of primarily non-numerical data obtained from observation, interviews, tape recordings, document, etc.

\subsection{Data and Data Source}

Data are the result of observation, consisting of the given thing that researcher analyzes (Dirnye, 2007: 41). The data are described and analyzed based on Molina and Albir's theory of translation techniques. The data in this research are utterances in the form of subtitles in the movie. While the source of data is taken from a Thai movie entitled "Crazy Rich Asian". "Crazy Rich Asian" is an American romantic comedy film released in 2018. 


\subsection{Technique of Collection Data}

The technique of collecting data used is documentation. Document analysis is a form of qualitative research in which documents are interpreted by the researcher to give voice and meaning around an assessment topic (Bowen, 2009). Bowen adds that the researcher must evaluate the original purpose of the document, such as the target audience. Documentation meant in this research is the result of translation done by the students from Indonesian text as a source language into English as a target language. In qualitative research, the instrument is the researcher herself. She is the one who should know well and have a broad knowledge on the topic of the research which is being discussed. In this case, the researcher must know well about the subtitle "Crazy Rich Asian" movie.

\subsection{Technique of Analyzing Data}

The following are the steps which are followed in analyzing data, such as classifying the dialogues in the novel, identifying the translation procedures that are applied in translating the subtitle "Crazy Rich Asian" movie and analyzing the dialogues translation with its translation technique.

\section{Results}

The purposes of this research are to find out the types of translation techniques and the most dominant type of translation technique used in subtitle "Crazy Rich Asian" movie. After collecting the data, the writer then identifies the type of translation techniques that are used in the subtitle movie. Each utterance of the dialogues in this movie is classified based on the types of translation technique which are defined by Molina \& Albir (2002). There are 18 types, such as 1. Adaptation; 2. Amplification (Addition); 3. Borrowing; 4. Calque; 5. Compensation; 6. Description; 7. Discursive Creation; 8. Established Equivalence; 9. Generalization; 10. Linguistic Amplification; 11. Linguistic Compression; 12. Literal Translation; 13. Modulation; 14. Particularization; 15. Reduction; 16. Substitution; 17. Transposition and 18. Variation.

In analyzing the type of translation technique, the researcher uses subtitle Crazy Rich Asian movie both English and Indonesian which contains 300 data (utterances of the dialogue in the movie). In the movie, there are some types of translation techniques which are used by the translator. Below the analysis of the study shows the frequency and percentages of the type of translation techniques used in subtitle Crazy Rich Asian movie. The description in the following table:

Table 1. Type of Translation Technique Used in Subtitle "Crazy Rich Asian" movie

\begin{tabular}{llcc}
\hline No & \multicolumn{1}{c}{ Type of Translation Technique } & Data & Percentage \\
\hline 1. & Shift/Transposition & $\mathbf{7 2}$ & $\mathbf{1 9 . 4 6}$ \\
\hline 2. & Literal & $\mathbf{7 0}$ & $\mathbf{1 8 . 9 2}$ \\
\hline 3. & Established Equivalence & 62 & $\mathbf{1 6 . 7 6}$ \\
\hline 4. & Reduction/Omission & 53 & $\mathbf{1 4 . 3 2}$ \\
\hline 5. & Borrowing & 52 & $\mathbf{1 4 . 0 5}$ \\
\hline 6. & Addition/Amplification & $\mathbf{3 0}$ & $\mathbf{8 . 1 1}$ \\
\hline 7. & Modulation & $\mathbf{2 6}$ & $\mathbf{7 . 0 3}$ \\
\hline 8. & Adaptation & $\mathbf{5}$ & $\mathbf{1 . 3 5}$ \\
\hline
\end{tabular}


According to the table above, there are 8 types of translation techniques used in subtitle Crazy Rich Asian movie. The type of translation techniques used are Shift/Transposition as 72 data or $19.46 \%$, Literal as 70 data or 18.92 $\%$, Established Equivalence as 62 data or $16.76 \%$, Reduction/Omission as 53 data or $14.32 \%$, Borrowing as 52 data or $14.05 \%$, Addition/Amplification as 30 data or $8.11 \%$, Modulation as 26 data or $7.03 \%$ and Adaptation as 5 data or $1.35 \%$. The descriptions are as follows:

\subsection{Transposition/Shift}

Transposition is where the location of various parts of speech within a sentence are switched based on the particular language. For example:

CODE : 008-CRA-M

SL : We spoke on the phone when I confirmed it yesterday.

TL : Kita sudah berbicara di telepon saat aku mengkonfirmasikannya kemarin.

\section{CODE : 0272-CRA-M}

SL : I'm going to ask the cook to make you some herbal soup.

TL : Aku akan meminta koki untuk membuatkan kau sup herbal.

In the examples above show a transposition/Shift technique. Those are categorized of the level shift. Level shift also means a shift from grammar to lexis. From the texts in the SL above, the level shift in the translation is indicated by the grammar in the source language (SL) which is translated into lexis in the target language (TL). In the first example, the word "spoke" in SL has a formula V2 (Past Tense) is translated into "sudah berbicara" in the TL. The second example, it is found that the grammatical item to be + -ing + to + V1 (pattern of Simple Future Tense) in the SL is translated into "sedang" in the TL. Level shift also happens in the third example because the form we'll (we will) has formula $S$ + will (pattern of Present Future Tense in English) in the SL is translated into the TL by using the lexis "akan".

CODE : 030-CRA-M

SL $\quad: \quad$... my family's long history as custodians of the Calthorpe is ended

TL : ... sejarah panjang keluargaku sebagai penjaga Calthorpe berakhir.

CODE : 164-CRA-M

SL : Aren't good Chinese sons supposed to stay with their parents?

TL : Bukankah putra Cina yang baik seharusnya tinggal dengan orang tua mereka?

CODE : 031-CRA-M

SL : I sell the hotel to my dear friend, the Young family of Singapore.

TL : Aku menjual hotel ini kepada teman-teman yang terkasihku, keluarga Young Singapura. 
From the example above show Transposition/Shift technique. Those are categorized of the level shift. Intra-system shift means a shift that occurs internally, within the system; that is for those cases where the source and the target language possess systems which approximately correspond formally as to their constitution, but when translation involves selection of a noncorresponding term in the target language system. In the first example, the word "custodians" in SL is translated into "penjaga" in the TL. In the second example, the word "sons" in SL is translated "putra" in the TL. Both of two examples show the category shift from plural in SL into singular in the TL. If the underlined words above are translated, it should be translated into "penjaga-penjaga" or "putra-putra" or the other translated it can be added by "para" to make plural nouns in the TL.

CODE : 095-CRA-M

SL : Every time I bring them up, Nick changes the subject.

TL : Setiap kali aku membawa mereka, Nick mengubah topik pembicaraan.

CODE : 113-CRA-M

SL : You speak Chinese.

TL : Kau berbicara bahasa Cina.

From the example above show Transposition/Shift technique. Those are categorized of the unit shift. Unit shift means as a change of rank, departures from formal correspondence in which the translation equivalent of a unit at one rank in the SL is a unit at a different rank in the TL. Both two examples above, show unit shift from the noun is changed into a noun phrase. In the first example, the word "subject" as a noun in SL is translated into "subject pembicaraan" as a noun phrase in TL. Then, in the second example, the word "Chinese" is a noun in SL is translated into "bahasa Cina" as a noun phrase in the TL".

\subsection{Literal Translation}

A literal translation can be used between some languages but not others. Literal translation, although it seems like it, is not a word-for-word translation. It is only used when the structures and concepts of the language run parallel to each other. For example:

CODE : 089-CRA-M

SL : You can't wear that to meet Nick Ah Ma.

TL : Kau tidak bisa memakai itu untuk bertemu Nick Ah Ma.

CODE : 079-CRA-M

SL : But Rachel and I will stay together.

TL : Tapi Rachel dan aku akan tinggal bersama.

CODE : 221-CRA-M

SL : I love you.

TL : Aku cinta kau. 
In the examples above show the Literal Translation Technique. The translator keeps the original content without changing structure, form or style. In the first example, the sentence "You can't wear that to meet Nick's Ah Ma" in SL is translated into "Kau tidak bisa memakai itu untuk bertemu Nick Ah Ma" in the $T L$. This sentence both $S L$ and $T L$ have same structure " $\mathrm{S}+\mathrm{V}+\mathrm{O}+$ Complement". In the second example, dependent clause "But Rachel and I will stay together" in SL is translated into "Tapi Rachel dan aku akan tinggal bersama." in the TL. This sentence both SL and TL have same structure "Conjunction + S + V+ O". While, In the third example, sentences "I love you" in $\mathrm{SL}$ is translated into "Aku cinta kau" in the TL. This sentence both SL and TL have same structure " $\mathrm{S}+\mathrm{V}+\mathrm{O}$ ".

\subsection{Established Equivalence}

When translating, maybe there are some phrases in some languages that simply cannot be expressed directly in other languages, which is where equivalence comes into play. For example:

CODE : 125-CRA-M

SL : Welcome aboard, Mr. Young, Miss Chu.

TL : Selamat datang, Tuan Muda, Nona Chu.

CODE : 194-CRA-M

SL : Good morning.

TL : Selamat pagi.

CODE : 207-CRA-M

SL : Wow! Oh, my gosh!

TL : Wow! Ya ampun!

CODE : 251-CRA-M

SL : Hello sir, how are you?

TL : Halo tuan, apa kabarmu?

CODE : 255-CRA-M

SL : Thank you, bye!

TL : Terima kasih, selamat tinggal!

In the examples above show Established Equivalence technique. It uses some daily situations, in our personal lives or common term which has been stated in the dictionary or it has been used in the society. In the first example, the phrase "Welcome aboard" in SL is translated into "Selamat datang". The phrase is related to the context of an airplane or boat. "Boarding" an airplane or boat means getting onto it. When we board an airplane or boat, the crew (people who work on the plane or boat) usually say "Welcome aboard.". In the second example, the expression "Good morning" in SL is translated into "Selamat pagi" in the TL. This expression is used as a greeting when meeting somebody for the first time in the morning. It is also defined as a polite greeting or farewell that you say to someone in the early hours of the day. In the third example, the phrase "Oh, my gosh" in SL is translated into "Ya ampun". It is much like "oh my god", or the shortened form "omg". The expression "oh my 
gosh" can also be condensed into "omg", and thus people will have no idea whether you are talking about god or gosh. In the fourth example, the expression, "How are you" in SL is translated into "Bagaimana kabarmu?". This expression makes a slightly more personal inquiry about someone's health or mood. It also focuses on the person's condition. The last, is the expression "Thank you" in SL is translated into "Terima kasih" in SL. It is expressing thankfulness or gratitude, then the expression of "bye" in SL is a phrase for formal or professional situations in the end of a conversation.

\subsection{Reduction/Ommision}

In reduction, the translator is more likely to reduce the number of elements that form the SL into TL. That is, the translator ought to make sure that no crucial information is omitted in the translation. According to Ivacovoni (2009: 1 ), omission means dropping a word or words from the SLT while translating. This procedure can be the outcome of the cultural clashes that exist between the SL and the TL. For example:

CODE : 060-CRA-M

SL : Did you know he had a girlfriend?

$\mathrm{TL} \quad$ : Apakah kau tahu dia punya pacar?

CODE : :.167-CRA-M

SL : $\quad$. Wow, I can't believe this airport has a butterfly garden, and a movie theater.

TL : 1.Wow, aku tidak percaya bandara ini memiliki taman kupukupu, dan bioskop.

CODE : : 165

SL : : I'm not a good son.

TL : : Aku bukan anak yang baik.

In the example above show Reduction/Omission technique. The translator reduces the information item in the TL. The word "a" as an article is not translated into the TL. If it is translated, it will be "suatu", "seorang" or "sebuah". For example, the article "a" in a phrase "a girlfriend", "a movie theater" and "a good soon" are not translated into "seorang pacar", "sebuah/suatu bioskop" or "seorang anak yang baik".

\subsection{Borrowing}

Borrowing is when words are taken from one language to another without any translation. Borrowing is also used when there is no word available in the target language to express the same idea; this can be seen when new concepts are described. The borrowing translation means a word taken directly from another language to create a stylistic effect. According to Molina and Albir (2002: 520), borrowing is divided in the two kinds. They are pure borrowing and naturalized borrowing. For example:

CODE : 012-CRA-M

SL : My family and I would like to be shown to our suite.

TL : Keluargaku dan aku ingin segera diantar ke kamar suite kita. 
CODE : 134-CRA-M

SL : My family has business with this airline.

TL : Keluargaku memiliki bisnis dengan maskapai ini.

CODE : 016-CRA-M

SL : ...your lovely family can find other accommodation.

TL : ...keluarga tercinta anda dapat menemukan akomodasi lain.

CODE : 101-CRA-M

SL $\quad$ :... you might just come back with a souvenir.

TL $\quad$ :... aku mungkin hanya kembali dengan souvenir.

CODE : 203-CRA-M

$\mathrm{SL} \quad$ : The gold is very brilliant.

CODE : 262-CRA-M

SL : You have a cocktail dress in your trunk?

TL : Kau memiliki gaun koktail di bagasimu?

In the examples above show Borrowing technique. In the first example, the word "suite" in SL is translated into "suite". Here, the translator uses the Pure Borrowing technique. It shows that the words are purely borrowed from the original into the TL. While, in the other examples, the words "accommodation", "souvenir", brilliant" and "cocktail" in SL is translated into "akomodasi", "souvenir", "brilian" and "koktail". Those examples words are naturalized to fit the spelling rules (with changing) into "ticket", "passport" and "mechanic" in the TL. Here, the translator uses Naturalized Borrowing technique.

\subsection{Amplification/Addition}

Amplification is adding the detailed information that is not found in the source language text. Additions to this technique are only information that is used to help convey messages or understand the reader. This addition cannot change the messages in the source language $(\mathrm{SL})$. For example:

CODE : 01-CRA-M

SL : Be careful, your fingers.

TL : Hati-hati, dengan jari-jarimu.

CODE : 061-CRA-M

SL : Nick dates many girls.

TL : Nick berkencan dengan banyak wanita.

CODE : 012

SL : My family and I would like to be shown to our suite.

TL : Keluargaku dan aku ingin segera diantar ke kamar suite kita.

CODE : 077

SL : And your room is all ready for you. 
TL : Dan kamarmu semua sudah siap untukmu

In the example above show Addition/Amplification technique. The translator adds the information item in the TL. Both in the first and second example above, there is addition item/word, especially class word in TL "dengan" which refers to the conjunction. While, in the third example, there is addition word "segera" in TL, and in the last example there is addition word "sudah" in TL.

\subsection{Modulation}

Modulation consists of altering a phrase from one language to another to convey the same meaning. This is commonly used when the translation of a phrase from one language to another is awkward. For example:

CODE : 03-CRA-M

SL : May I help you?

TL : Bisa kubantu?

CODE : 009-CRA-M

SL : Sorry, you don't seem to have a reservation.

TL : Maaf, sepertinya tidak ada reservasi dengan nama Anda.

CODE : 014-CRA-M

SL : We're fully booked, madam.

TL : Hotel kami tidak ada kamar kosong, Nyonya.

In the example above show Modulation technique. Here, the translator changes the point of view in SL into TL without altering the meaning and without generating a sense of awkwardness in the reader of the target language (TL). In the first example, the sentences "May I help you?" in SL is translated into "Bisa kubantu?". It shows the same meaning. In the second example, the sentences "Sorry, you don't seem to have a reservation" in SL is translated into "Maaf, sepertinya tidak ada reservasi dengan nama Anda". It shows the same meaning. Then, in the last example, the sentences "We're fully booked, madam" in SL is translated into "Hotel kami tidak ada kamar kosong, Nyonya" also have the same meaning.

\subsection{Adaptation}

Adaptation is when something that is expressed in one culture is expressed in a completely different way in another culture. It is commonly seen in references to pop culture. For example:

CODE : 187-CRA-M

SL : But it's my bachelor party this weekend, and I would you to come.

TL : Tapi ini pesta lajangku akhir pekan ini dan aku ingin kau datang.

CODE : 017-CRA-M

SL : May I suggest you explore Chinatown?

TL : Bisa aku menyarankan anda untuk menjelajahi Pecinan? 


\section{CODE : 039-CRA-M \\ SL : Yeah, you always say that, and then you end up eating all my dessert. \\ TL : Ya, kau selalu mengatakan itu, dan kemudian kau akhirnya makan semua pencuci mulutku.}

In the examples above show Adaptation technique. The translator here replaces the SL cultural elements with one which has the same condition and situation in the TL culture. In the first example, the word "Bachelor Party" in SL is translated into "Pesta Lajang" in TL. Bachelor party is a party held a party for a man who is going to get married, to which only his male friends are invited. The second example, the word "Chinatown" in SL is translated into "Pecinan" in the TL. Chinatown is a subzone and ethnic enclave located within the Outram district in the Central Area of Singapore. Featuring distinctly Chinese cultural elements, Chinatown has a historically concentrated ethnic Chinese population. The next example, the word "Dessert" in SL is translated into "Pencuci Mulut" in the TL. Dessert is the last course of a meal. In the United States, dessert is likely to consist of pastry, cake, ice cream, pudding, or fresh or cooked fruit. While in Singapore, the desserts are cakes and tarts, waffles and s'mores, to a three-course omakase dessert menu - paired with sake.

Translation technique is the realization of the translation process such as method and strategy of translation. According to Molina \& Albir (2002: 508), it refers to translation product and works for the micro unit of the text. According to Molina and Albir (2002: 510-511), there are 18 kinds of translation techniques, namely: 1) Adaptation, 2) Amplification, 3) Borrowing, 4) Calque, 5) Compensation, 6) Description, 7) Discursive Creation, 8) Established Equivalence, 9) Generalization, 10) Linguistic Amplification, 11) Linguistic Compression, 12) Literal Translation, 13) Modulation, 14) Particularization, 15) Reduction, 16) Substitution 17) Transposition, and 18) Variation.

There are 8 types of translation techniques found in the subtitle Crazy Rich Asian movie. The type of translation techniques used are 1) Shift/Transposition as 72 data or $19.46 \%$, 2) Literal as 70 data or $18.92 \%, 3$ ) Established Equivalence as 62 data or $16.76 \%$, 4) Reduction/Omission as 53 data or $14.32 \%, 5)$ Borrowing as 52 data or $14.05 \%, 6)$ Addition/Amplification as 30 data or $8.11 \%, 7$ ) Modulation as 26 data or $7.03 \%$ and 8) Adaptation as 5 data or $1.35 \%$. While the most dominant type of translation technique of English to Indonesian subtitle of "Crazy Rich Asian" movie is shift/transposition.

The first rank is Shift/Transposition as 72 data or $19.46 \%$. Transposition is where the location of various parts of speech within a sentence are switched based on a particular language. From the analysis above, it found some type of shift they are level, intra-system, and unit shift. 1) The level shift also means a shift from grammar to lexis. In the first example, the word "spoke" in SL has a formula V2 (Past Tense) is translated into "sudah berbicara" in the TL. The second example, the grammatical item to be + -ing + to + V1 (pattern of Simple Future Tense) in the SL is translated into "sedang" in the TL. Level shift also happens in the third example because the form we'll (we will) has formula $S+$ will (pattern of Simple Future Tense in English) in the SL is translated into the TL by using the lexis "akan". 2) The intra - system shift means a shift that 
occurs internally, within the system; that is for those cases where the source and the target language possess systems which approximately correspond formally as to their constitution. In the first example, the word "custodians" in SL is translated into "penjaga" in the TL. In the second example, the word "sons" in $\mathrm{SL}$ is translated "putra" in the TL. Both of two examples show the category shift from plural in SL into singular in the TL. If the underlined words above are translated, it should be translated into "penjaga-penjaga" or "putra-putra" or the other translated it can be added by "para" to make plural nouns in the TL. 3) The unit shift means as a change of rank, departures from formal correspondence in which the translation equivalent of a unit at one rank in the $S L$ is a unit at a different rank in the TL. Both two examples above, show unit shift from the noun is changed into a noun phrase. In the first example, the word "subject" as a noun in SL is translated into "subject pembicaraan" as a noun phrase in the TL. Then, in the second example, the word "Chinese" is a noun in $\mathrm{SL}$ is translated into "Bahasa Cina" as a noun phrase in the TL".

The second rank is Literal as 70 data or $18.92 \%$. Literal is only used when the structures and concepts of the language run parallel to each other, allowing the proper imagery and style to come through. In the examples above show the Literal Translation Technique. The translator keeps the original content without changing structure, form or style. In the first example, the sentence "You can't wear that to meet Nick's Ah Ma" in SL is translated into "Kau tidak bisa memakai itu untuk bertemu Nick Ah Ma" in the TL. This sentence both SL and $T L$ have same structure " $\mathrm{S}+\mathrm{V}+\mathrm{O}+$ Complement". In the next example, dependent clause "But Rachel and I will stay together" in SL is translated into "Tapi Rachel dan aku akan tinggal bersama" in the TL. This sentence both SL and TL have same structure "Conjunction $+S+V+O$ ". While, In the third example, the sentence "I love you" in SL is translated into "Aku cinta kau" in the $T L$. This sentence both SL and TL have same structure " $\mathrm{S}+\mathrm{V}+\mathrm{O}$ ".

The third rank is Established Equivalence as 62 data or $16.76 \%$. Equivalence is a technique that uses some daily situations, in our personal lives or common term which has been stated in the dictionary or it has been used in society. In the first example, the phrase "Welcome aboard" in SL is translated into "Selamat datang". The phrase is related to the context of an airplane or boat. "Boarding" an airplane or boat means getting onto it. In the second example, the expression "Good morning" in SL is translated into "Selamat pagi" in the TL. This expression is used as a greeting when meeting somebody for the first time in the morning. In the third example, the phrase "Oh, my gosh" in SL is translated into "Ya ampun". It is much like "oh my god", or the shortened form "omg". In the fourth example, the expression, "How are you" in SL is translated into "Bagaimana kabarmu?". This expression makes a slightly more personal inquiry about someone's health or mood. It also focuses on the person's condition. The last, is the expression "Thank you" in SL is translated into "Terima kasih" in SL. It is expressing thankfulness or gratitude, then the expression of "bye" in SL is a phrase for formal or professional situations at the end of a conversation.

The fourth rank is Reduction/Omission as 53 data or $14.32 \%$. In reduction, the translator is more likely to reduce the number of elements that 
form the SLT. That is, the translator ought to make sure that no crucial information is omitted in the translation. The word "a" as a determiner/article is not translated into the TL. If it is translated, it will be "suatu", "seorang" or "sebuah". For example, the article "a" in a phrase "a girlfriend", "a movie theater" and "a good soon" are not translated into "seorang pacar", "sebuah/suatu bioskop" or "seorang anak yang baik".

The fifth rank is Borrowing as 52 data or $14.05 \%$. Borrowing is used when words are taken from one language to another without any translation. Borrowing is also used when there is no word available in the target language to express the same idea; this can be seen when new concepts or technology are described. The borrowing translation means a word taken directly from another language. It is used to create a stylistic effect. According to Molina and Albir (2002: 520), borrowing is divided into two kinds. They are pure borrowing and naturalized borrowing. In the first example, the word "suite" in SL is translated into "suite" which shows the Pure Borrowing technique. It shows that the word is purely borrowed from the original into the TL. While, in the other examples, the words "accommodation", "souvenir", brilliant" and "cocktail" in SL is translated into "akomodasi", "souvenir", "brilian" and "koktail". Those examples words are naturalized to fit the spelling rules (with changing) into "ticket", "passport" and "mechanic" in the TL which show Naturalized Borrowing technique.

The sixth rank is Addition/Amplification as 30 data or $8.11 \%$. Amplification is adding detailed information that is not found in the source language text. This technique is the only information that is used to help convey messages or understand the reader. In the example above show that there is an addition item/word, especially class word in TL "dengan" which refers to the conjunction. Then, addition word "segera" and "sudah" in the TL.

The seventh rank is Modulation as 26 data or $7.03 \%$. Modulation consists of uttering a phrase from one language to another to convey the same meaning. From the example, the translator changes the point of view in SL into TL without altering meaning. In the first example, the sentences "May I help you?" in SL is translated into "Bisa kubantu?". It shows the same meaning. In the second example, the sentences "Sorry, you don't seem to have a reservation" in SL is translated into "Maaf, sepertinya tidak ada reservasi dengan nama Anda". It shows the same meaning. Then, in the last example, the sentences "We're fully booked, madam" in SL is translated into "Hotel kami tidak ada kamar kosong, Nyonya" also have the same meaning.

The last rank is Adaptation as 5 data or $1.35 \%$. The translator here replaces the SL cultural elements with, one which has the same condition and situated in the TL culture. In the first example, the word "Bachelor Party" in SL is translated into "Pesta Lajang" in the TL. The bachelor party is a party held a party for a man who is going to get married, to which only his male friends are invited. The second example, the word "Chinatown" in SL is translated into "Pecinan" in the TL. Chinatown is a subzone and ethnic enclave located within the Outram district in the Central Area of Singapore. Featuring distinctly Chinese cultural elements, Chinatown has a historically concentrated ethnic Chinese population. The next example, the word "Dessert" in SL is translated into "Pencuci Mulut" in the TL. Dessert is the last course of a meal. In the United 
States, dessert is likely to consist of pastry, cake, ice cream, pudding, or fresh or cooked fruit. While in Singapore, the desserts are cakes and tarts, waffles and s'mores, to a three-course omakase dessert menu - paired with sake.

\section{Conclusion}

There are 8 types of translation techniques found in the subtitle Crazy Rich Asian movie. The type of translation techniques used are Shift/Transposition as 72 data or $19.46 \%$, Literal as 70 data or $18.92 \%$, Established Equivalence as 62 data or $16.76 \%$, Reduction/Omission as 53 data or $14.32 \%$, Borrowing as 52 data or $14.05 \%$, Addition/Amplification as 30 data or $8.11 \%$, Modulation as 26 data or $7.03 \%$ and Adaptation as 5 data or 1.35 $\%$. While the most dominant type of translation technique of English to Indonesian subtitle of "Crazy Rich Asian" movie is shift/transposition. Transposition is where the location of various parts of speech within a sentence are switched based on a particular language. From the analysis above, it found some type of shift they are level, intra-system, and unit shift.

\section{References}

Airasian, P., \& L.R. Gay. (2000). Educational Research: Competence for Analysis and Application (6th ed.). New Jersey: Merrill Prentice Hall.

Arikunto, Suharsimi. 2002. Prosedur Penelitian, Suatu Pendekatan Praktek. Jakarta: PT Rineka Cipta

Bowen, G. A. (2009). Document Analysis as a Qualitative Research Method. Qualitative Research Journal, 9(2), 27-40. doi:10.3316/QRJ0902027

Dirnye, Zoltan. 2007. Research Method in Applied Linguistic, Qualitative, Quantitative, and Mixed Methodologies. New York: Oxford University Press

Fitria, T. N. (2019). Translation Technique of English into Indonesian Subtitle in "Bhaijan Bajrangi" Movie. ELS Journal on Interdisciplinary Studies in Humanities, 2(2), 253-265.

Hopwood, Sean. (July 27, 2016). Translation Techniques: Compensating for Differences Between Languages. Retrieved January 10, 2019 from https://www.seanhopwood.com/blog/translation/2016/07/translationtechniques-compensating-for-differences-between-languages-5049

Ivacovoni, A. (2009). Translation by Omission. Retrieved from: http://iacovoni.wordpress.com/2009/02/01/translation-by-omission/ .

Molina, L. and Albir Hurtardo. 2002. 'Translation Techniques Revisited: A Dynamic and Functionalist Approach". Meta: Translators' Journal, vol. 47, no.4, 2002, p. 498- 512. Retrieved on Retrieved January 10, 2019 from http://id.erudit.org/iderudit/008033ar

Osman, Amira. 2017. Definition of Translation. Retrieved January 10, 2019 from https://translationjournal.net/October-2017/definition-of-translation.html

Racoma, Bernadine (June 1, 2015). The Main Aspects of Film Translation. $\begin{array}{llll}\text { Retrieved January } & 10, & 2019 & \text { from }\end{array}$ 
https://www.daytranslations.com/blog/2015/06/the-main-aspects-of-filmtranslation-6292/

Rowan, Kiri. (April 30, 2014). Translation Techniques: Battling Discrepancies Between Languages. Retrieved January 10, 2019 from https://blog.udemy.com/translation-techniques/

Seah, Jaclynn. (November 22, 2018). Crazy Rich Asians: The Real Lives of Singapore's Elite. Retrieved January 16, 2019 from https://theculturetrip.com/asia/singapore/articles/crazy-rich-asians-the-reallives-of-singapores-elite/

Torres, C.C. 2003. Latinos in rural America. In: Brown, D.L. and Swanson, L.E. (eds.). Challenges for Rural America in the Twenty-first Century. University Park, PA: The Pennsylvania State University Press: 57-70.

Truong, Peggy. (January, 19, 2019). What You Need to Know About the 'Crazy Rich Asians' Movie Sequel. Retrieved January 16, 2019 from https://www.cosmopolitan.com/entertainment/movies/a22686749/crazyrich-asians-movie-sequel/ 